\title{
Influence of cooking methods on bioactive compounds in beetroot
}

\section{Compostos bioativos em beterrabas submetidas a diversas formas de cozimento}

\author{
Juliana Arruda Ramos ${ }^{1 *}$; Karina Aparecida Furlaneto'; \\ Veridiana Zocoler de Mendonça ${ }^{1}$; Flávia Aparecida de Carvalho Mariano-Nasser²; \\ Giovanna Alencar Lundgren ${ }^{3}$; Erika Fujita ${ }^{4}$; Rogério Lopes Vieites ${ }^{5}$
}

\begin{abstract}
Beetroot is rich in bioactive compounds that may provide health benefits. However, vegetable tissues are physically and chemically damaged by cooking, causing major changes to compounds in cell membranes. The current study aimed to evaluate the influence of several cooking methods on bioactive compounds in beetroot. Four heat treatments were carried out: steam cooking, pressure cooking, baking in an oven, and boiling in water. Beets were matched in uniformity of size, color, and absence of defects. They were washed thoroughly in running water to remove dirt. Next, one of the four cooking methods was applied. After cooking, beets were peeled by hand. Analysis was carried out on both uncooked and cooked beets to evaluate antioxidant activity, content of phenolic compounds, pigments, flavonoids, and betalains. The experiment was completely randomized design (CRD) and carried out in triplicate. Data were subjected to analysis of variance $(\mathrm{F}$ test, $\mathrm{p}<0.05)$ and mean values compared by Tukey test at $5 \%$ probability. There was no change in antioxidant activity or total phenolic and anthocyanin content by any of the cooking methods compared to that in raw beetroots. However, pressure-cooking resulted in lower carotenoid levels compared to that in raw beet. Furthermore, flavonoid and betalain content decreased by all the cooking methods.
\end{abstract}

Key words: Antioxidants. Anthocyanins. Betalains. Beta vulgaris. Carotenoids. Flavonoids.

\section{Resumo}

A beterraba é rica em compostos bioativos, que possuem efeitos benéficos para o organismo humano. Porém o cozimento dos tecidos vegetais altera física e quimicamente as propriedades da parede celular, afetando o teor desses compostos. O objetivo do trabalho foi avaliar os compostos bioativos em beterrabas in natura e submetidas a diversas formas de cozimento. Foram realizados quatro tratamentos térmicos, sendo eles cocção a vapor, cocção na panela de pressão, no forno e na água em imersão. As beterrabas foram selecionadas visando a homogeneização do lote quanto ao tamanho, cor e ausência de injúrias e defeitos. Foram lavadas em água corrente para tirar as sujidades. Em seguida, levadas às quatro formas de cocção. Após os tratamentos térmicos, foram descascadas manualmente. As análises realizadas nas beterrabas in natura e cozidas foram a atividade antioxidante, teor de compostos fenólicos totais,

\footnotetext{
${ }^{1}$ Discentes, Programa de Pós-Graduação em Agronomia- Energia na Agricultura, Universidade Estadual Paulista, UNESP, Faculdade de Ciências Agronômicas, Botucatu, SP, Brasil. E-mail: ju.a.ramos@globo.com; karina_furlaneto@globo.com; veridianazm@yahoo.com.br

${ }^{2}$ Discente de Pós-Doutorado, Programa de Pós-Graduação em Agronomia, Horticultura, UNESP, Faculdade de Ciências Agronômicas, Botucatu, SP, Brasil. E-mail: flaviamariano1@hotmail.com

3 Discente, Programa de Pós-Graduação em Agronomia, Horticultura, UNESP, Faculdade de Ciências Agronômicas, Botucatu, SP, Brasil. E-mail: giolundgren@gmail.com

${ }^{4}$ Prof ${ }^{a}$, Faculdade de Ensino Superior e Formação Integral, FAEF, Garça, SP, Brasil. E-mail: erikafujita79@hotmail.com

5 Prof. Titular, Departamento de Horticultura, UNESP, Faculdade de Ciências Agronômicas, Botucatu, SP, Brasil. E-mail: vieites@ fca.unesp.br

* Author for correspondence
} 
pigmentos, flavonoides e betalaínas. O experimento seguiu o Delineamento Inteiramente Casualizado (DIC) com três repetições. Os dados foram submetidos a análise de variânca, teste $\mathrm{F}$, e as médias comparadas pelo Teste de Tukey $(\mathrm{p}<0,05)$. Não houve perdas na atividade antioxidante, fenólicos totais e antocianinas em todas as formas de cocção estudadas em relação à beterraba crua. Somente a cocção na pressão apresentou menores teores de carotenoides em relação a crua. As concentrações de flavonoides e de betalaínas diminuíram em todas as formas de cozimento.

Palavras-chave: Antioxidantes. Antocianinas. Betalaínas. Beta vulgaris. Carotenoides. Flavonoides.

\section{Introduction}

Vegetables are important sources of antioxidant compounds, such as vitamin $\mathrm{C}$ and $\mathrm{E}$, phenolic compounds, and carotenoids. These compounds are widely distributed in plants and have biological properties that promote human health; therefore, fruits and vegetables have been encouraged for human consumption (CAMPOS et al., 2008, MELO et al., 2009). Dark fruits and dark green/ red vegetables (e.g. beets) contain high levels of phenolic and flavonoid compounds (LIN; TANG, 2007), which have shown to have potent biological effects such as antioxidant, anti-inflammatory, antitumor, and platelet aggregation inhibitory activities. Flavonoid intake is positively associated with an increase in life expectancy and a decrease in incidence of cardiovascular disease (VOLP et al., 2008). Additionally, dietary intake of carotenoids and phenolic compounds has been associated with prevention of numerous degenerative diseases (SILVA et al., 2010).

Anthocyanins are the pigments responsible for blue, purple, and red color, and are present in high concentrations in beet. The antioxidant potential of anthocyanins could be more than double compared to that of commercial antioxidants like vitamin E, and have improved activity compared with butylhydroxyanisole (BHA) and butylhydroxytoluene (BHT) (MACHADO et al., 2013). Betalains are also responsible for the coloration of beets. This compound is derived from secondary metabolism of a diverse group of secondary metabolites that contain nitrogen and is a powerful antioxidant that scavenges free radicals, which may suppress the development of malignant tumors (PICOLI et al., 2010; TIVELLI et al., 2011).
Food processing is crucial from a nutritional viewpoint, as it can affect the content, activity, and bioavailability of both nutrients and antioxidants. Processing may lead to beneficial transformations, compound degradation, or nutrient loss (MELO et al., 2009). Cooking of vegetable tissues alters the physicochemical properties of the cell wall, which in turn affects their performance as dietary fiber (CARVALHO et al., 2003). For example, the whitening effect from cooking purple cauliflower using heat dramatically decreased the anthocyanin content, whereas microwave cooking did not show any difference compared to the raw vegetable (LO SCALZO et al., 2008).

According to some studies, cooking methods have influenced antioxidant content. Galgano et al. (2007) reported a 34\% reduction in vitamin C content in broccoli after cooking in water for 15 minutes, 22.4\% after steam cooking for 23 minutes, $8 \%$ after pressure-cooking for 2 minutes; and 9\% after microwave cooking for 11 minutes. In leafy vegetables, cooking resulted in $12 \%, 14 \%$, and $20 \%$ reduction of phenolic compounds in kale, spinach, and cabbage, respectively, after 1 minute of boiling (ISMAIL et al., 2004). However, Miglio et al. (2008) observed an increase in antioxidant capacity in carrots, zucchini, and broccoli after cooking in water, steaming, and frying. According to this study, this result was most likely due to the vegetable matrix softening and increased extractability of compounds, which could be partially converted into more antioxidant chemical species. The authors also mention that treatment by immersion in water better preserves the carotenoid content in the three vegetables and ascorbic acid in carrots and zucchini. Cooking methods that involve immersion in hot water resulted in an increase in carotenoid 
content in pumpkin, taro, and beet (SINGH et al., 2015). These changes might be due to the increased extraction capacity of carotenoids in the cellular system by boiling in water.

Changes induced by heat treatment, whether beneficial or not, depend on the vegetable type as well as preparation factors, such as slicing, time, cooking temperature, and cooking method, since they directly influence the content of bioactive compounds; thus, studies should be carried out on various vegetables to establish the best cooking method when preparing them. The current study aimed to evaluate the influence of several cooking methods on bioactive compounds of both uncooked and cooked beetroot.

\section{Material and Methods}

The hybrid Borus cultivar was used, purchased from the Dalbon farm in São José do Rio Pardo, São Paulo State, Brazil (geographical coordinates $21^{\circ} 35^{\prime} 45^{\prime \prime} \mathrm{S}$ and $\left.46^{\circ} 53^{\prime} 23^{\prime \prime} \mathrm{W}\right)$. Immediately after purchase, they were transported by road to the Laboratory of Nutrition and Dietetics in the Institute of Biosciences of the Sao Paulo State University, Botucatu. Subsequently, the lots were homogenized manually. Plants were selected according to uniformity of size, color and absence of defects. They were then washed thoroughly in running water to remove soils.

All cooking methods were tested beforehand to establish the correct cooking time for beets to be "al dente" (COPETTI et al., 2010). The times applied in the current study are shown in Table 1. Four heat treatments were carried out: steaming, pressure-cooking, oven-baking using aluminum foil wrap to cook evenly at $200^{\circ} \mathrm{C}$, and water immersion cooking. For each cooking method, eight beets were used, weighing around 2 kilograms. After cooking, the beets were manually peeled using a knife. Once peeled, they were frozen in liquid nitrogen; they were then macerated and frozen for biochemical analysis.

Table 1. Cooking times for each treatment for the beetroots.

\begin{tabular}{cc}
\hline TREATMENT & COOKING TIME (hour:min) \\
\hline Steaming & $01: 18$ \\
Pressure & $00: 30$ \\
Oven-baked & $03: 00$ \\
Water immersion & $01: 05$ \\
\hline
\end{tabular}

The antioxidant activity of both uncooked and cooked beet was measured by DPPH (MENSOR et al., 2001) and expressed as reduction of $\%$ DPPH. The total phenolic compound content was determined by Folin-Ciocalteau's spectrophotometric method (SINGLETON et al., 1999) and expressed in mg of gallic acid/100 $\mathrm{g}^{-1}$ of sample. The pigment content was determined as described by Linder (1974), expressed in mg $100 \mathrm{~g}^{-1}$ of beetroot. Flavonoid content was determined by the spectrophotometric method adapted from Santos and Blatt (1998); $4 \mathrm{ml}$ of acidified methanol solution was added to $0.1 \mathrm{~g}$ of sample, homogenized and placed in an ultrasonic bath for 30 minutes. $1 \mathrm{ml}$ of $5 \%$ aluminum chloride solution in methanol was added and left to stand in the dark for 30 minutes. Afterwards, the solution was centrifuged for 20 minutes at 6000 $\times \mathrm{g}$ and the absorbance at $425 \mathrm{~nm}$ read using a spectrophotometer. Results are expressed in $\mathrm{mg}$ of rutin $100 \mathrm{~g}^{-1}$. Betalain content was determined as described by Stintzing et al. (2005) and expressed in $\mathrm{mg} 100 \mathrm{~g}^{-1}$.

The experiment was a completely randomized design (CRD) with three replicates. Data were subjected to analysis of variance (F test, $\mathrm{p}<0.05$ ) and means compared by Tukey test at $5 \%$ probability. 


\section{Results and Discussion}

Antioxidant activity of raw beetroot was $57.63 \%$, with no statistically significant difference ( $>0.05)$ between any of the cooking methods (Table 2). Monreal et al. (2009) analyzed the influence of cooking methods on antioxidant activity in vegetables and showed that beet retained its antioxidant activity when assessed by several antioxidant activity quantification methods. This result is similar to that of the current study that showed that antioxidant capacity was maintained in all treatments. Lin and Chang (2005) reported that cooking broccoli for 10 minutes at $50^{\circ} \mathrm{C}$ or for 8 minutes at $100^{\circ} \mathrm{C}$ did not alter antioxidant capacity by DPPH method; similar to other studies, the current study showed that various cooking methods did not alter antioxidant properties of beets. Melo et al. (2009) studied the antioxidant activity of a variety of vegetables subjected to heat treatment and showed that cooking did not drastically affect their antioxidant properties. This may be due to compensation by newly formed compounds, such as those of the Maillard reaction, or because a compound having partial oxidation to donate hydrogen atom to the hydroxyl radical and/ or the polyphenol aromatic structure to tolerate the displacement of unpaired electron around the ring (NICOLI et al., 1999).

Table 2. Mean values of antioxidant capacity in percentage of reduced DPPH (\%) and phenolic compounds (mg 100 $\left.\mathrm{g}^{-1}\right)$ in raw and cooked beetroots.

\begin{tabular}{ccc}
\hline Cooking method & DPPH & Phenolic compounds \\
\hline Steaming & $61.57 \mathrm{a}$ & $84.06 \mathrm{a}$ \\
Pressure & $46.32 \mathrm{a}$ & $64.20 \mathrm{a}$ \\
Oven-baked & $44.07 \mathrm{a}$ & $64.82 \mathrm{a}$ \\
Water immersion & $43.58 \mathrm{a}$ & $57.46 \mathrm{a}$ \\
Raw & $57.63 \mathrm{a}$ & $77.81 \mathrm{a}$ \\
\hline CV\% & 14.90 & 16.64 \\
\hline
\end{tabular}

Means followed by equal letters in the column do not differ from each other by the Tukey test $(\mathrm{p}<0.05)$.

There was no significant difference in the concentration of phenolic compounds between uncooked and cooked beets. This can be explained by the increased extraction of phenolic compounds from the cellular matrix, due to changes in texture that occur during cooking (BLESSINGTON et al., 2010). Campos et al. (2008) reported that extracting phenolic compounds in raw vegetables is still a barrier when evaluating the influence of heat treatments on them, because some studies have shown higher extraction in cooked vegetables.

The concentration of anthocyanins (Table 3) found in raw beet was $85.2 \mathrm{mg} 100 \mathrm{~g}^{-1}$, consistent with reports by Macagnan et al. (2015) $(83.7 \mathrm{mg}$ $\left.100 \mathrm{~g}^{-1}\right)$, both expressed on a wet basis. There was no influence of the treatments $(p>0.05)$ on anthocyanin concentration in beets. In a study on fruits and vegetables cooked at different temperatures for different periods of time, Machado et al. (2013) showed a positive correlation between exposure time and temperature $\left(50^{\circ} \mathrm{C}\right)$ for anthocyanin concentration in all samples, probably due to the higher extraction of anthocyanin pigments.

There was a $54.9 \%$ decrease in the carotenoid concentration of pressure-cooked beets compared to

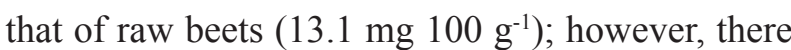
was no significant difference compared to other cooking methods (Table 3 ). Some previous studies have stated that carotenoids are lost during cooking, whereas others have found opposite responses, such as no loss or an increase in carotenoid concentration, making it difficult to evaluate carotenoid retention in cooked foods (CAMPOS, 2008). 


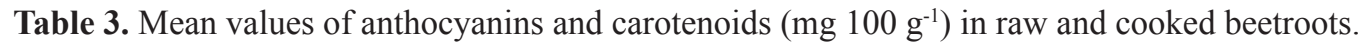

\begin{tabular}{ccc}
\hline Cooking method & Anthocyanins & Carotenoids \\
\hline Steaming & $69.8 \mathrm{a}$ & $10,0 \mathrm{ab}$ \\
Pressure & $40.3 \mathrm{a}$ & $5.9 \mathrm{~b}$ \\
Oven-baked & $48.8 \mathrm{a}$ & $7.6 \mathrm{ab}$ \\
Water immersion & $49.8 \mathrm{a}$ & $7.7 \mathrm{ab}$ \\
Raw & $85.2 \mathrm{a}$ & $13.1 \mathrm{a}$ \\
\hline CV\% & 28.81 & 25.89 \\
\hline
\end{tabular}

Means followed by equal letters in the column do not differ from each other by the Tukey test $(\mathrm{p}<0.05)$.

The concentration of flavonoids (Table 4) in raw beet was higher (290.64 mg rutin $100 \mathrm{~g}^{-1}$ ) than that in cooked beets. Pressure-cooked beets showed the largest reduction in flavonoid content $(70.8 \%)$. There was no significant difference in flavonoid content among steamed beets, oven-baked beets, and those immersed in water. Pellegrini et al. (2010) showed similar results, observing a $50 \%$ decrease in the concentration of flavonoids in broccoli when cooked in boiling water.

Table 4. Mean values of flavonoids (mg rutin $100 \mathrm{~g}^{-1}$ ) in raw and cooked beetroots.

\begin{tabular}{cc}
\hline Cooking method & Flavonoids \\
\hline Steaming & $141.81 \mathrm{~b}$ \\
Pressure & $84.79 \mathrm{c}$ \\
Oven-baked & $122.37 \mathrm{bc}$ \\
Water immersion & $109.34 \mathrm{bc}$ \\
Raw & $290.64 \mathrm{a}$ \\
\hline CV\% & 11.15 \\
\hline
\end{tabular}

Means followed by equal letters in the column do not differ from each other by the Tukey test $(\mathrm{p}<0.05)$.

Table 5 shows the betalain concentration, which is the sum of betacyanin and betaxanthin. The concentration of betalain found in raw beets was $49.51 \mathrm{mg} 100 \mathrm{~g}^{-1}$. This result is similar to that found by Picoli et al. (2010), who reported betalain

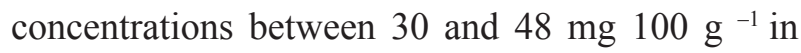
raw whole beets. It is known that betalains are lost at high temperatures, which explains the decrease in betalain concentration by all cooking methods (CONSTANT et al., 2002). Beets cooked in a pressure cooker had the highest loss $(59.5 \%)$ compared to raw beet (49.51 mg $100 \mathrm{~g}^{-1}$ ); however, there was no statistically significant difference compared with oven-baked beets $(40.4 \%)$. Cooking methods that best preserved betalain content in beets were those immersed in water and steamed (31.74 and $32.21 \mathrm{mg}$ $100 \mathrm{~g}^{-1}$, respectively). In a previous study conducted with blanched beets, there was a decrease of almost $10 \%$ in betalain concentration compared to that in raw beets (ZABOTTI et al., 2013). In the current study the betalain content decreased by $35 \%$ when immersed in water, probably due to the longer time when compared with blanching. 


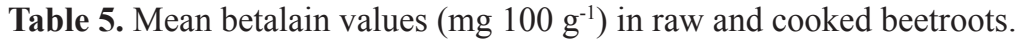

\begin{tabular}{cccc}
\hline Cooking method & Betacyanin & Betaxanthin & Betalain \\
\hline Steaming & $20.98 \mathrm{~b}$ & $11.23 \mathrm{~b}$ & $32.21 \mathrm{~b}$ \\
Pressure & $13.25 \mathrm{c}$ & $6.78 \mathrm{c}$ & $20.02 \mathrm{c}$ \\
Oven-baked & $17.56 \mathrm{bc}$ & $11.90 \mathrm{~b}$ & $29.46 \mathrm{bc}$ \\
Water immersion & $20.56 \mathrm{~b}$ & $11.19 \mathrm{~b}$ & $31.74 \mathrm{~b}$ \\
Raw & $31.63 \mathrm{a}$ & $17.88 \mathrm{a}$ & $49.51 \mathrm{a}$ \\
\hline CV\% & 12.87 & 10.2 & 11.81 \\
\hline
\end{tabular}

Means followed by equal letters in the column do not differ from each other by the Tukey test $(\mathrm{p}<0.05)$.

\section{Conclusion}

There was no significant difference in antioxidant activity, and total phenolic and total anthocyanin content by any of the cooking methods compared to raw beetroots. However, pressure-cooking lowered carotenoid levels compared to raw beets. Flavonoid and betalain content decreased by all the cooking methods.

\section{References}

BLESSINGTON, T.; NZARAMBA, M. N.; SCHEURING, D. C.; HALE, A. L.; REDDIVARI, L.; MILLER JR., J. C. Cooking methods and storage treatments of potato: effects on carotenoids, antioxidant activity, and phenolic. American Journal of Potato Research, New York, v. 87, n. 6, p. 479-491, 2010.

CAMPOS, M. F.; MARTINO, H. S. D.; SABARENSE, C. M.; PINHEIRO-SANT'ANA, H. M. Estabilidade de compostos antioxidantes em hortaliças processadas: uma revisão. Alimentos e Nutrição, Araraquara, v. 19, n.4, p. 481-490, 2008.

CARVALHO, D. V.; ABREU, P. M. C.; SANTOS, T. A. M. Efeito de diferentes tempos de cozimentos nos teores de minerais em folhas de brócolis, couve-flor e couve. Ciência e Agrotecnologia, Lavras, v. 27, n. 3, p. 597-604, maio/jun. 2003.

CONSTANT, P. B. L.; STRINGHETA, P. C.; SANDI, D. Corantes alimentícios. B. CEEPA, Curitiba, v. 20, n. 2, p. 203-220, 2002.

COPETTI, C.; OLIVEIRA, V. R.; KIRINUS, P. Avaliação da redução de potássio em hortaliças submetidas a diferentes métodos de cocção para possível utilização na dietoterapia renal. Revista de Nutrição, Campinas, v. 23, n. 5 , p. 831-838, 2010.
GALGANO, F.; FAVATI, F.; CARUSO, M.; PIETRAFESA, A.; NATELLA, S. The influence of processing and preservation on the retention of healthpromoting compounds in broccoli. Journal of Food Science, Chicago, v. 72, n. 2, p. 130-S135, 2007.

ISMAIL, A.; MARJAN, Z. M.; FOONG, C. H. Antioxidant activity and phenolic content in selected vegetables. Food Chemistry, Amsterdam v. 87, n. 4, p. 581-586, 2004.

LIN, C. H.; CHANG, C. Y. Textural change and antioxidant properties of broccoli under different cooking treatments. Food Chemistry, Amsterdam, v. 90, n. 1, p. 9-15, 2005.

LIN, J. Y.; TANG, C. Y. Determination of total phenolic and flavonoid contents in selected fruits and vegetables, as well as their stimulatory effects on mouse splenocyte proliferation. Food Chemistry, Amsterdam, v. 10, n.1, p. 140-147, 2007.

LINDER, S. A proposal for the use of standardized methods for chlorophyll determinations in ecological and ecophysiological investigations. Physiologia Plantarum, Copenhagem, v. 32, n. 2, p. 154-56, 1974.

LO SCALZO, R.; GENNA A.; BRANCA, F.; CHEDIN, M.; CHASSAIGNE, H. Anthocyanin composition of cauliflower (Brassica oleracea L. var.botrytis) and cabbage (B. oleracea L. var. capitata) and its stability in relation to thermal treatments. Food Chemistry, Amsterdam, v. 107, n. 1, p. 136-144, 2008.

MACAGNAN, C. C.; RIGHES, F. W.; TERRA, L. M.; SALVAlAGGIO, R.; SCHMALTZ, S. Análise da retenção de antocianina em beterrabas desidratadas através de métodos combinados de secagem. In: CONGRESSO BRASILEIRO DE ENGENHARIA QUIIMICA EM INICIAÇÃO CIENTÍFICA UNICAMP, 3., Campinas, 2015. Anais... Campinas: Blucher, 2015. p. $1950-1955$. v. 1 . 
MACHADO, W. M.; PEREIRA, A. D.; MARCON, M. V. Efeito do processamento e armazenamento em compostos fenólicos presentes em frutas e hortaliças. Publicatio UEPG Exactand Earth Sciences, Agrarian Sciences and Engineering, Ponta Grossa, v. 19, n. 1, p. 17-30, 2013.

MELO, E. de A.; MACIEL, M. I. S.; LIMA, V. L. A. G. de; SANTANA, A. P. M. de. Capacidade antioxidante de hortaliças submetidas a tratamento térmico. Nutrire: Revista da Sociedade Brasileira de Alimentação e Nutrição, São Paulo, v. 34, n. 1, p. 85-95, 2009.

MENSOR, L. L. MENEZES, F. S.; LEITÃO, G. G.; REIS, A. S.; SANTOS, T. C. dos.; COUBE, C. S.; LEITÃO, S. G. Screening of Brazilian plant extracts for antioxidant activity by the use of DPPH free radical method, Phytotherapy Research, Chichester, v. 15, n. 2, p. 127-130, 2001.

MIGLIO, C.; CHIAVARO, E.; VISCONTI, A.; FOGLIANO, V.; PELLEGRINI, N. Effects of different cooking methods on nutritional and physicochemical characteristics of selected vegetables. Journal Agriculture of Food Chemestry, v. 56, n. 1, p. 139-147, 2008.

MONREAL, A. M. J.; DIZ, L. G.; TOMÉ, M. M.; MARISCAL, M.; MURCIA. M. A. Influence of cooking methods on antioxidant activity of vegetables. Journal of Food Science, Chicago, v. 74, n. 3, p. 97-103, 2009.

NICOLI, M. C.; ANESE, M.; PARPINEL, M. Influence of processing on the antioxidant properties of fruit and vegetables. Trends Food Science and Technology, Kidlington, v. 10, n. 3, p. 94-100, 1999.

PELlEGRINI, N.; CHIAVARO, E.; GARDANA, C.; MAZZEO, T.; CONTINO, D.; GALLO, M.; RISO, P.; FOGLIANO, V.; PORRINI, M. Effect of different cooking methods on color, phytochemical concentration, and antioxidant capacity of raw and frozen Brassica vegetables. Journal of Agricultural and Food Chemistry, Washington, v. 58, n. 7, p. 4310-4321, 2010.

PICOLI, A. A.; FARIA, D. B.; JOMORI, M. L. L.; KLUGE, R. A. Avaliação de biorreguladores no metabolismo secundário de beterrabas inteiras e minimamente processadas. Tecnologia de pós-colheita. Bragantia, Campinas, v. 69, n. 4, p. 983-988, 2010.
SANTOS, M. D.; BLATT, C. T. T. Teor de flavonoides e fenóis totais em folhas de Pyrostegia venusta Miers. de mata e de cerrado. Revista Brasileira de Botânica, São Paulo, v. 21, n. 2, p. 135-140, 1998.

SILVA, M. L. C.; COSTA, R. S.; SANTANA, A. S.; KOBLITZ, M. G. B. Compostos fenólicos, carotenóides e atividade antioxidante em produtos vegetais. Semina: Ciências Agrárias, Londrina, v. 31, n. 3, p. 669-682, 2010 .

SINGH, S.; SWAIN, S.; SINGH, D. S.; SALIM, K. M.; NAYAK, D.; ROY, S. D. Changes in phytochemicals, anti-nutrients and antioxidant activity in leafy vegetables by microwave boiling with normal and $5 \% \mathrm{NaCl}$ solution. Food Chemistry, Washington, v. 176, n. 1, p. 244-253, 2015.

SINGLETON, V. L.; ORTHOFER, R.; LAMUELA, R. M. Analysis of total phenols and other oxidation substrates and antioxidants by means of Folin-Ciocalteau reagent, Methods of Enzymology, New York, v. 299, n. 1, p. 152-178, 1999.

STINTZING,F.C.;HERBACH,K.M.;MOSSHAMMER, M. R.; CARLE, R.; YI, W.; SELLAPPAN, S.; AKOH, C. C.; BUNCH, R.; FELKER, P. Color, Betalain Pattern, and Antioxidant Properties of Cactus Pear (Opuntia spp.) Clones. Journal of Agricultural and Food Chemistry, München, v. 53, n. 2, p. 442-451, 2005.

TIVELLI, S. W.; FACTOR, T. L.; TERAMOTO, J. R. S.; FABRI, E. G.; MORAES, A. R. A. de; TRANI, P. E.; MAY, A. Beterraba: do plantio à comercialização. Campinas: Instituto Agronômico, 2011. 45 p. (Série Tecnologia APTA).

VOLP, A. C. P.; RENHE, I. R. T.; BARRA, K.; STRINGUETA, P. C. Flavonóides antocianinas: características e propriedades na nutrição e saúde. Revista Brasileira de Nutrição Clínica, Paraíso, v. 23, n. 2, p. 141-149, 2008.

ZABOTTI, C.; GENENA, A. K. Avaliação do potencial antioxidante do extrato obtido a partir da beterraba vermelha (Beta vulgaris L.) por meio do uso da água como solvente de extração. Cultivando o Saber, Cascavel, v. 6, n. 4, p. 195-200, 2013. 
